（特集）口腔粘膜疾患への光診断の応用

歯科用 OCT 画像診断機器の開発と歯科臨床応用

\author{
角保徳 \\ 国立長寿医療研究センター歯科口腔先進医療開発センター \\ 歯科口䏶先端診療開発部 \\ （受付： 2012 年 8 月 15 日, 受理 : 2012 年 9 月 14 日)
}

\title{
The Development of a Dental Optical Coherence Tomography System and Its Clinical Application to the Diagnosis of Oral Diseases
}

\author{
Yasunori SUMI \\ Department for Advanced Dental Research Center of Advanced Medicine for Dental \\ and Oral Diseases National Center for Geriatrics and Gerontology \\ (Received: August 15, 2012, Accepted for Publication: September 14, 2012)
}

\begin{abstract}
Optical coherence tomography (OCT) is a new biomedical imaging modality which can generate high-resolution, cross-sectional images of microstructures in biological systems. One of the most attractive features of OCT is that it uses safe near-infrared light instead of hazardous ionizing radiation. Furthermore, resolution on the order of 10 micrometers can be obtained. The optical accessibility of clinically relevant structures in the oral cavity makes it a particularly attractive location for the application of OCT imaging techniques. Our National Center for Geriatrics and Gerontology has developed a new sweptsource optical coherence tomography (SS-OCT) system through joint research with industry and the public sector. In this study, this new SS-OCT system was applied to cross-sectional imaging of dental caries, resin based composite restorations, periodontal disease, oral cancer and finished dentures. It is concluded that our new SS-OCT system is a promising new and useful alternative imaging technique which can safely provide much more definitive information on oral structures at far higher resolution than is possible by conventional clinical imaging methods. The National Center for Geriatrics and Gerontology received the world's first production unit of this new dental SS-OCT system.
\end{abstract}

(J. Jpn. Soc. Laser Dent. $23: 137 \sim 141,2012$ Reprint requests to Dr. SUMI)

Key words = Dental OCT imaging device, Optical coherence tomography (OCT), Nondestructive inspection, High resolution, Diagnostic device

キーワード=歯科用 OCT 画像診断機器, 光干渉断層画像診断法, 非侵襲検査, 高解像度, 画像診断機器

\section{OCT とは}

近年, 生体医療用光学分野の進歩は著しく, その中でも 新時代の医療用検査機器として光干涉断層画像診断法 (Optical Coherence Tomography: 以下 OCT) が注目を 浴びている。OCT は, 生体に無害な近赤外レーザー光と 光学干渉計の応用により, 被写体内部から得られた後方散 乱光を解析することで, 非侵襲下に組織断面の高解像度断 層画像を描出することができる最先端の画像撮像技術であ る。さらに, CT や MRI の数十倍の解像度で組織の精密
断層像を得ることができる。これらの特性により, 歯科に OCT を応用することでパノラマレントゲン装置以来の口 腔領域の新たな画像診断機器となる可能性を有する。国立 長寿医療研究センター歯科口腔先端診療開発部では, OCT の非侵襲性, 高分解能, 客観性, 同時性, 低価格性 などの特性を生かして, 産学官共同で歯科用 OCT 画像診 断機器の開発を進め, 日本発, 世界初の製品化を目指し, 系統的に研究開発を進めている（図 1)。

干 474-8511 愛知県大府市森岡町源吾 35 番地 TEL 0562-46-2311 FAX 0562-44-8518

35, Gengo, Morioka-cho, Obu Aichi 474-8511, Japan. TEL +81-562-46-2311 FAX + 81-562-44-8518 


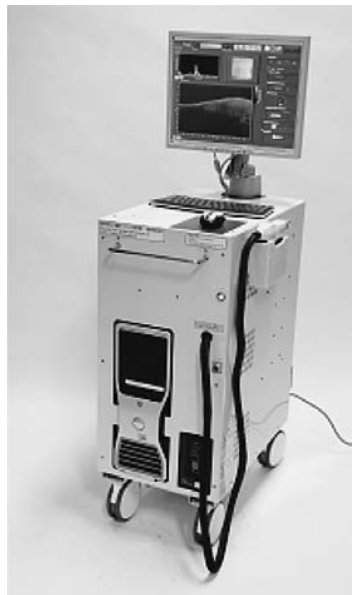

図 1 現在国立長寿医療研究センターにて共同開発中の歯科 用 OCT 画像診断機器の全体像。比較的小型で移動が 可能である。

\section{2. 歯科用 OCT 画像診断機器開発の経緯}

国立長寿医療研究センターにおける歯科用 OCT 画像診 断機器の開発の発端は, 平成 17 年 10 月に東洋経済社の 「会社四季報秋号」を何気なく捲っていたときに，愛知県 小牧市にあるJASDAQ 上場企業が「体断層を動画的に見 る光レーザーの開発が着実に進渉」という文言が目にと まったことに始まる。筆者は当時, 厚生労働省長寿医療研 究委託費 “高齢者の咀嚼嚥下に関する機能の評価方法並び に回復法に関する研究”の主任研究者を務めており, 摂 食・嚥下機能障害患者のVFやVEの動画を研究していた。 「体断層を動画的に見る光レーザーが摂食・嚥下機能障害 の診断に使えないか」と考え, 企業に連絡をしたところ, 技術者に来院いただき OCT の基本技術と構造について説 明を受け,「OCTにより歯周病の精密検査の代用ができる のではないか」と考え，その場で直ちに秘密保持契約を結 び, 研究開発の発端となった。

以後，多くの方々のご協力をいただき，製品化へ向け研 究開発が進んでいる。開発当初 3 年間はほとんど研究費も なく手弁当で研究開発を行ってきたが, 平成 21 年度より 長寿医療研究開発費など総額 1 億 7200 万円を超える研究 費が採択され研究が一気に進渉した。

\section{OCT の原理と基本構成}

今回開発した歯科用 OCT 画像診断機器システムの構成 を図 2 に示す。

OCT の原理は，まず生体に近赤外レーザー光が照射さ れた場合, 生体内部からはその内部構造の異なる深さから 光が元の方向（後方）に散乱される。OCT 装置に内蔵さ れた干渉計により，減衰され戻ってくる後方散乱光を参照 光と干渉させることによって, 異なる深さにある内部構造

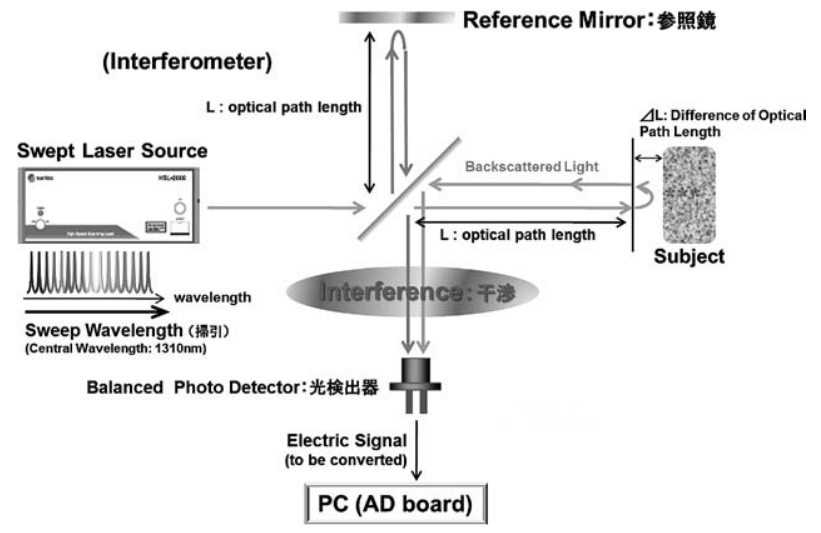

図 2 歯科用 OCT 画像診断機器システムの構成 OCT の基本構成は, 近赤外帯域のレーザー光源, 干渉計, 検出部分, 信号処理部, ディスプレイ, プローブ部から成 り，極めて単純な構造である。

OCT は光の干渉現象を用いることによって, 生体などを 断層画像として観察・測定できる装置である。毎秒 2 万回 の高速な掃引（波長 $1260 \sim 1360 \mathrm{~nm}$ ）を行う波長走查型 レーザー光源から射出された近赤外レーザー光は分光器で コントロールの参照光 (縦 $\rightarrow)$ と, 被写体に向かう観察光 (横 $\rightarrow)$ に分割される。観察光は被写体内部を深達しなが ら散乱光を発するが，そのうち受光部で捉えられる後方散 乱光は, 光ファイバーで光学干渉計まで伝達される。参照 光と後方散乱光は光学カプラで合波され干渉し, 光検出器 で電気信号に変換される。得られた信号はデジタル化され た後，光源のトリガ信号と同期され，高速フーリエ変換な どの数理学処理にて被写体内の各深度における散乱係数に 従って, リアルタイムにデイスプレイに断層像として表示 される。

物とその位置を光強度対干渉周波数の情報に置き換えるこ とができる。今回われわれが開発に取り組んだ歯科用 OCT 画像診断機器は, レーザー光源の発振波長を連続的 に挿引しながら時間的にフーリエ分析する方法を採用する 波長走査型光干涉断層画像装置 (swept-source Optical Coherence Tomography: SS-OCT) であり, 本研究では このSS-OCTを採用して測定を行った。SS-OCT はモー ションアーチファクトに強い事からも実際の臨床に利用し やすく, レーザー光源の性能によっては画像分解能も空気 中約 $11 \mu \mathrm{m}$ （組織中約 $8.0 \mu \mathrm{m} ）$ と高分解能と高速撮像を 実現できる点で優れている。

\section{OCT の長所と短所}

\section{1）高解像度}

OCT は表層下数ミリメートルの比較的浅い組織の断層 画像を, CT P MRI などの既存の画像診断技術と比べて 極めて高い解像度でリアルタイムに得られることも特徴で ある。OCT の空間分解能が約 $10 \mu \mathrm{m}$ と解像度が高いため, CT P MRI な゙現在用いられている画像診断機器よりも 数十倍の解像度の断層画像を撮影することができ，これま での画像診断機器では不可能であった生体の微細構造や病 
変が検出できる。将来的には癌などの診断に生検による病 理組織学的検査に代わり, 非侵襲検査としての光生検が可 能になることが期待される。

2）非侵襲性

日本人の発癌の $3.2 \%$ は医療診断用放射線によるとラン セット誌における報告 ${ }^{1)}$ があり, さらに，米国では 2007 年の 1 年間に CT 検査により, 米国で毎年発症する癌の約 $2 \%$ に相当する約 2.9 万人が癌になる計算であると報告さ れた ${ }^{2)}$ 。癌など生命にかかわる病気なら診断の必要性に応 じて被曝も仕方がないが, 将来的には歯科診断など生命に 関わらない診断の照射回数の制限が行われると考えられ る。今後, X 線や CT で不可避であったこの問題を気にす ることなく頻回に撮影可能であるという点で, 歯科診療に おける OCT の重要性は増すものと考えられる。厚生労働 省も平成 24 年度厚生労働科学研究費補助金として, 低侵 襲診断・治療機器開発分野（24070201）をテーマとしてあ げている。

3）同時性

歯科用 OCT 画像診断機器は, チェアサイドでリアル夕 イムにディスプレイに断層像として表示が可能であり, 術 者が画像を評価しながら診断や治療を進めることができる ようになった。さらに, 患者へのインフォームド・コンセ ントにも有効である。

4）シンプルな構造

OCT の構成は, 上述のように極めてシンプルな構造で あり, CT・MRI など他の画像診断機器に比較して小型, 軽量であるため, 容易に移動が可能であり設置場所もス ペースをとらない。加えて, 電磁放射線の流出も無いため 遮蔽施設の建造も不要である。CT・MRIに比して安価で 製造できる利点も有り, 費用対効果比の面でも期待できる。

5）短所 : 浅い光到達深度

短所として, 近赤外レーザー光を利用しているので OCT は画像として取得できる情報が, 軟組織では表層か ら $1 \sim 2 \mathrm{~mm}$ 程度（歯牙のような透過性の良い組織では 2 〜 $3 \mathrm{~mm}$ ) とごく浅い部分しか観察できないことが挙げら れている。

\section{5. 歯科用 OCT 画像診断機器の基礎研究}

現在のう蝕診断技術の多くは視診, 触診や X 線写真が 主体で, 歯科医師の技量や経験により診断が左右される傾 向にある。

歯科用 OCT 画像診断機器で得られたう蝕の断層像と実 際のう蝕の範囲の整合性を評価するために, OCT 画像と 病理組織学的所見との比較を行ったところ, それぞれの OCT 画像に対応する部分の病理組織像でもほとんど同様 の所見が得られた（図 3 )。

他に抜去歯牙でのレジン充填の評価, 歯科用レジン充填
の光重合時の OCT リアルタイムビデオ評価, 歯䯣腔イ メージング, 根管の評価, 乳歯への応用等を口腔外で系統 的に行い, 歯科用 OCT 画像診断機器の有効性を確認した 上で, 当センター倫理・利益相反委員会承認の下, 臨床研 究を開始した。

\section{6. 歯科用 OCT 画像診断機器の臨床研究}

1）レジン充填の臨床評価と治療

レジンは近赤外レーザー光を透過させる率が高いので, 比較的深い組織の断層画像を得ることが出来る ${ }^{3)}$ 。図 4 に レジン充填の臨床所見とその OCT 画像を示す。臨床所見 では判断できなかった積層充继や空洞などが OCT 像にて 明確に確認できる。

2）う蝕の臨床診断と治療

歯科用 OCT 画像診断機器を用いると, 口腔内でも歯牙 の内部構造が精密に描写されることが判明し, 初期う蝕, エナメル質う蝕, 象牙質う蝕の鑑別診断が治療前に可能と なった。

3) 歯科用 OCT 画像診断機器の歯周病への応用

歯周病の診断にはポケットプロービングが頻用される が, 客観性にそしい, 侵襲検查である, 時間とコストがか かるなど多くの問題点が存在する。歯科用 OCT 画像診断 機器では, 歯周組織の内部構造を直接画像上で観察するこ とができるので, 歯周病の診断がより正確になることが期 待される。

4) 歯科用 OCT 画像診断機器の口腔癌・ 口胫軟組織病 変への応用

わが国に打ける口腔癌の発生頻度は人体に発生する癌の うち $1 \%$ 強を占め, 毎年およそ数千人が命を落としてお り, 口腔領域では極めて重要な疾患である。歯科用 OCT 画像診断機器を用いて, 口腔癌の撮影を行い正常組織と癌 組織との内部構造の形態の違いを明瞭に確認可能であっ た ${ }^{4)}$ (図 5)。比較的アプローチのし易い口腔癌で技術蓄積 することにより OCT 診断技術が確立されることで, 肺癌 や消化器癌など医科領域の癌の診断への応用が期待され る。

さらに, 血管腫 ${ }^{5)}$, 線維腫などの良性腫瘍, 白板症, 扁 平苔癄, Sjögren 症候群 ${ }^{6)}$ などの口腔粘膜疾患に応用して いる。

5）歯科用 OCT 画像診断機器の義歯の非破壊検査への 応用

高齢社会を迎え, 義歯の品質向上, 品質管理は急務であ る。歯科用 OCT 画像診断機器を用いると義歯の内部の構 造が非破壊検査で確認でき, 気泡, 材料欠陥, 義歯の破折 を義歯装着前に発見できることから, 義歯補綴治療の予知 性と義歯使用患者 QOL の向上が期待でき, 材料の物性向 上や新規材料開発に寄与することができる77。 


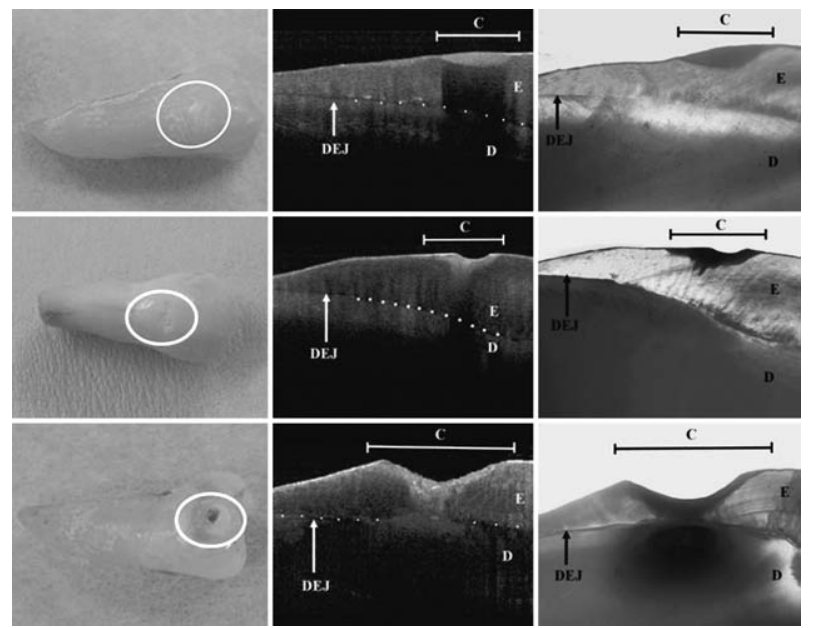

図 3 初期う蝕の抜去歯牙の肉眼所見, OCT 像, 病理組 織像

「初期う蝕」(図 3 上段),「エナメル質う蝕」(図 3 中段), 「象牙質う蝕」(図 3 下段) について左から写真, OCT 画 像および組織像を示す。

初期う蝕の OCT 像では表面の欠損を伴わずエナメル質内 に限局する高輝度部分を確認できた（図 3 上段中）。

エナメル質う蝕はエナメル質表面の欠損を伴い, エナメル 象牙境を越えずにエナメル質内に限局する高輝度部分を認 めた（図 3 中段中）。

象牙質う蝕では歯質の欠損を伴って，エナメル質とエナメ 儿象牙境を越えて象牙質にまで及ぶ高輝度部分を認めた (図 3 下段中)。

これらのう蝕はそれぞれ OCT 画像上で明らかに異なった 画像を呈していた。それぞれの OCT 画像に対応する部分 の組織像でもほほ同様の所見が得られた（図 3 上中下段, 右)。
6) 口腔内光学印象と CAD/CAM システムとの結合（特 許出願中）（図 6)

OCT の極めて高い解像度を応用することで，精密な口 腔内印象が可能である。本機器を用いた口腔内光学印象法 と CAD/CAM 技術を統合し，日本が世界に誇る光工学技 術と精密加工技術を融合し, 革新的な歯科修復・補綴治療 法の開発を行っている。

7）口腔インプラント手術時のガイドとしての有用性の

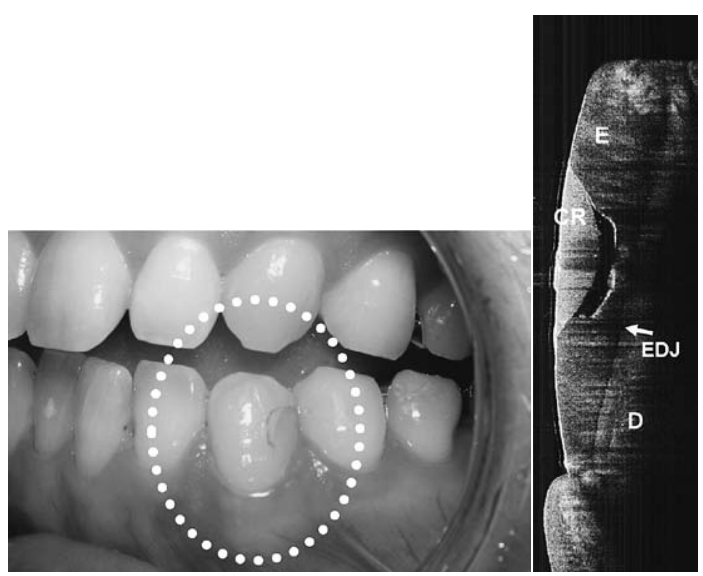

図 4 レジン充填の臨床所見とその OCT 画像 レジン充填の臨床所見とその OCT 画像 (矢状断像) を示す。高分子材料であるレジンは従来の X 線診 査では評価できないが，OCT 像にて臨床所見では 判断できなかった積層充填や空洞などが, 明確に 確認できる。

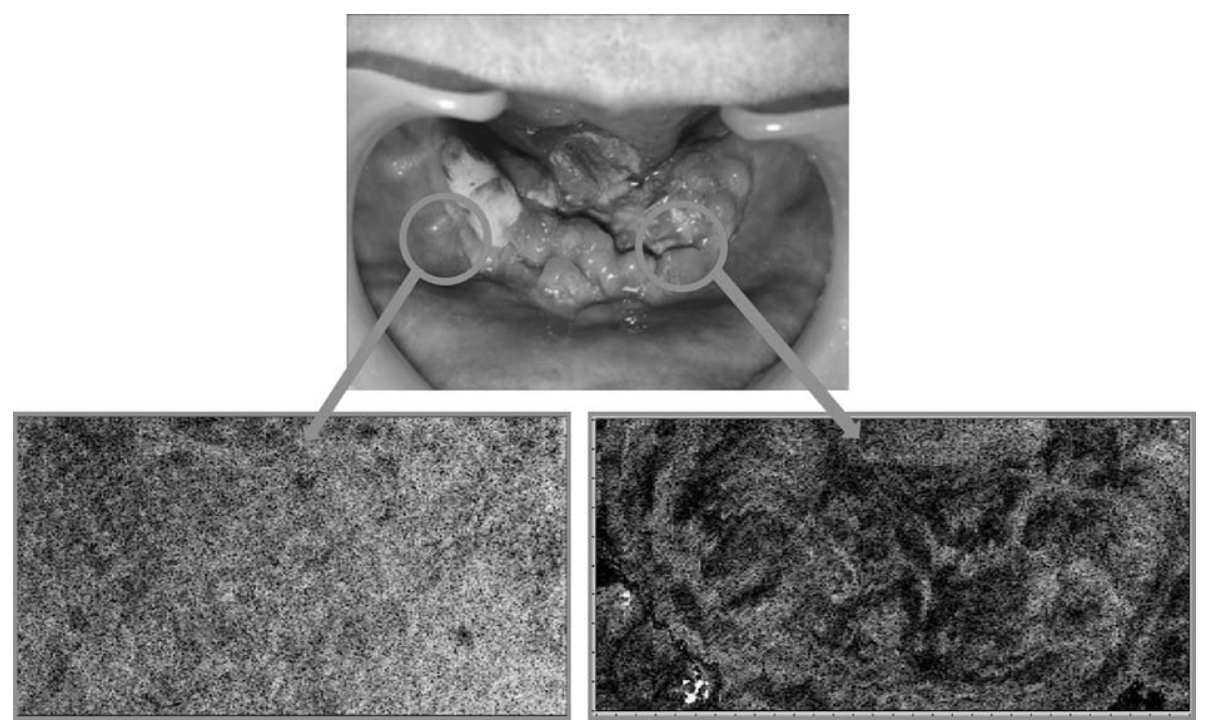

図 5 歯科用 OCT 画像診断機器の口腔癌への応用 ${ }^{4)}$ (文献 4 より一部転載)

上：初診時口腔内臨床所見。左 $\bigcirc$ 正常粘膜所見。右○は扁平上皮癌の臨床所見。

下：癌病変部と正常歯肉粘膜部の OCT 画像（水平断）。右に示す癌病変部では低信号部分 および高信号部分が交錯し，不均一な内部構造を示唆する像を認めた。一方，左の正 常歯肉粘膜部では, びまん性の比較的均一な内部構造を認めた。 


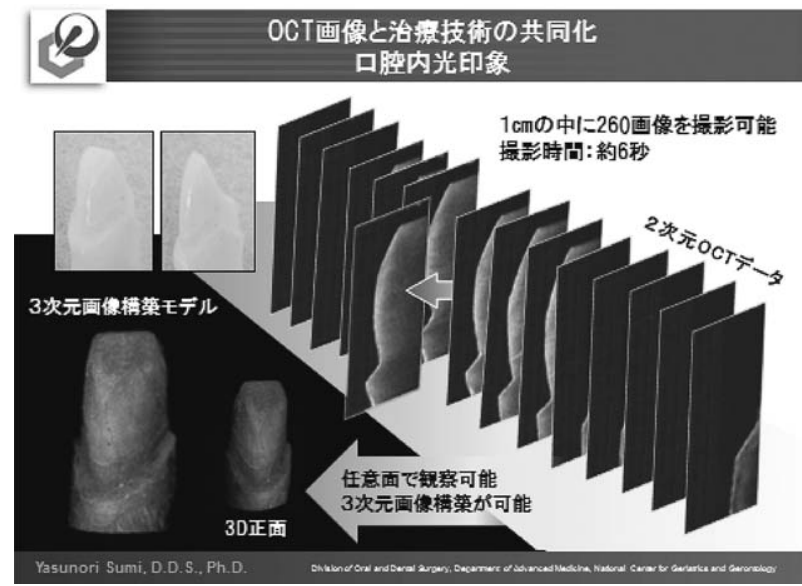

図 6 歯冠修復・補綴物に対する OCT の応用（口腔内光 印象と $\mathrm{CAD} / \mathrm{CAM}$ システムとの結合）により，口 腔内に数秒間光を照射することで歯の印象を採得 し，その情報を $\mathrm{CAD} / \mathrm{CAM}$ システムに送ることに より 20 分ほどで歯冠補綴物を臨床の現場で完成す ることができる。

\section{検討（特許出願中）}

インプラント手術中, 重要臓器損傷の回避のために, 歯 科用 OCT 画像診断機器を用いて, 下歯槽神経管や動静脈 までの距離を診断する。

\section{7. 日本発，世界初の新たな歯科用光干渉断層 画像診断機器の製品化に向けて}

国立長寿医療研究センターのチームでは, 歯科用 OCT 画像診断機器の開発を進め, 既に 13 件の特許出願を行い, ヒト口腔癌 ${ }^{4)}$, 口腔良性腫瘍 ${ }^{5)}$, 小唾液腺 ${ }^{6)}$, 義歯 ${ }^{7)}$ など の診断に OCT の有効性を報告してきた。現在, パノラマ レントゲン装置以来の新たな歯科用画像診断機器として, 日本発, 世界初の新たな歯科用 OCT 画像診断機器の製品 化を目指している。

歯科用 OCT 画像診断機器を口腔疾患診断に導入するこ
とで期待できることとして，以下を挙げることができる。

1）診断面においては, 非侵襲下にて, 歯周疾患診断, 口腔硬組織・軟組織診断などが画像化・数值化でき 客観性のある適切な診断が可能となる。

2）診療面において，X線のように為害作用がなく, チェアサイドで即時的にかつ頻繁に撮影することが 可能であり，治療精度の向上が期待できる。

3）健診面において，口腔内診査を行う歯科医師の主観 に頼る歯科健診ではなく, 客観性のある歯科健診シ ステムを構築することができるようになる。

4）患者へ画像情報を的確に提供でき, インフォームド コンセントにも有効に利用することが可能となる。

5）各種口腔疾患の早期客観的診断により早期治療が可 能となり医療費の適正化にも寄与することが期待で きる。

\section{文献}

1) Berrington de González A, Darby S: Risk of cancer from diagnostic X-rays: estimates for the UK and 14 other countries. Lancet, $363:$ 345-351, 2004.

2) Berrington de González A, Mahesh M, Kim KP, et al: Projected cancer risks from computed tomographic scans performed in the United States in 2007. Arch Intern Med, 169 : 2071-2077, 2009.

3) Ishibashi K, Ozawa N, Tagami J, et al: Swept-source optical coherence tomography as a new tool to evaluate defects of resin-based composite restorations. J Dent, 39 : 543-548, 2011.

4）寺沢史誉, 小澤総喜, 下郷和雄, 他 : 光干渉断層画像診断法 の口腔癌への応用. 日本口腔検査学会誌, 2:60-64, 2010.

5) Ozawa N, Sumi Y, Chong C, et al: Evaluation of oral vascular anomalies using OCT imaging. Br J Oral Maxillofac Surg, $47: 622-626,2009$.

6) Ozawa N, Sumi Y, Shimozato K, et al: In-vivo OCT images of human labial glands. Oral Surg Oral Med Oral Pathol, $108:$ 425-429, 2009.

7) Sumi Y, Ozawa N, Nagaosa S, et al: Application of optical coherence tomography to nondestructive inspection of dentures. Arch Gerontol Geriatr, 53 : 237-241, 2011. 